\title{
ГЕНЕТИКА ЦУКРОВОГО ДІАБЕТУ 2 ТИПУ ТА ЙОГО ПОЄДНАННЯ 3 ОЖИРІННЯМ І ХРОНІЧНИМ ПАНКРЕАТИТОМ
}

Вступ. Гени відіграють важливу роль у розвитку цукрового діабету 2 типу (T2DM). Дослідники запропонували взаємодію між безліччю генетичних фракторів та фракторів навколишнього середовища, що сприяють розвитку захворювання. Досягнення технологій генотипування та генетичної інформації полегшили застосування досліджень асоціацій, що стосуються геномів для виявлення генів сприйнятливосmi до T2DM. Протягом останнього десятиліття в рамках досліджень асоціацій генома (GWAS) зі збільшенням розміру вибірки було виявлено 144 генетичні варіанти в 129 локусах, асоційованих з T2DM.

При пошуку літературних джерел щодо спільного генетичного підгрунтя T2DM і хронічного панкреатиту (CP) встановлено, що поєднання T2DM+CР можуть зумовлювати генетичні варіанти T2DM. Учені виявили, що особи з T2DM+CP частіше страждають від надмірної маси тіла або ожиріння та мають сімейний анамнез цукрового діабету порівняно з тими, хто страждає від СР та не має діабету. При T2DM+CP поглиблюється дисфункція бета-клітин унаслідок хронічного запалення та фріброзу підшлункової залози, що, ймовірно, сприяє загибелі бета-клітин і нездатності компенсувати резистентність до інсуліну, це поглиблює перебіг діабету та панкреатиту. Генетичне зіставлення T2DM+CP та T2DM за SNP, які асоціюються з T2DM відповідно до GWAS, не відображає загальної ролі генетики, яку можна було б очікувати від послідовності цілого генома і всебічного аналізу всіх відомих генетичних варіантів, пов'язаних зі складною патобіологією захворювань підилункової залози та/або діабету.

Мета дослідження - проаналізувати сучасні літературні джерела про генетичні маркери, які беруть участь у механізмах розвитку цукрового діабету 2 типу та його поєднаного перебігу з ожирінням $і$ хронічним панкреатитом.

Висновок. Велика кількість досліджень дає підстави сподіватися, що в майбутньому дослідження генетики цукрового діабету за умови його коморбідного перебігу дозволять розробити ефрективні профрілактичні й терапевтичні засоби лікування, проте на даний час необхідно детально вивчити роль поліморфрізмів різних генів, особливо тих, що мають значення в патогенезі кожного окремого захворювання, у сприйнятливості до коморбідного перебігу цукрового діабету 2 типу.

КЛЮЧОВІ СЛОВА: цукровий діабет 2 типу; ожиріння; хронічний панкреатит; коморбідність; гени.

Гени відіграють важливу роль у розвитку цукрового діабету 2 типу (T2DM). Дослідники запропонували взаємодію між безліччю генетичних фракторів та фракторів навколишнього середовища, що сприяють розвитку захворювання [1]. Досягнення технологій генотипування та генетичної інорормації полегшили застосування досліджень асоціацій, що стосуються геномів для виявлення генів сприйнятливості до T2DM. Протягом останнього десятиліття в рамках досліджень асоціацій генома (GWAS) зі збільшенням розміру вибірки було виявлено 144 генетичні варіанти в 129 локусах, асоційованих з T2DM [2-5].

Метою дослідження було проаналізувати сучасні літературні джерела про генетичні маркери, які беруть участь у механізмах розвитку (с) У. П. Гевко, М. І. Марущак, 2020. цукрового діабету 2 типу та його поєднаного перебігу з ожирінням і хронічним панкреатитом.

Серед виявлених нуклеотидних поліморфізмів (SNP) деякі з них впливають на T2DM за рахунок зниження чутливості до інсуліну, тоді як більшість проявляє свій еорект через порушення фуункції бета-клітин $[2,6]$. Нещодавно при найбільш всебічному і детальному вивченні френотипових ефектів асоційованих з діабетом локусів було окреслено 9 локусів, пов'язаних з фрункцією бета-клітин, та 4 локуси з інсулінорезистентністю (IP) або нечутливістю до інсуліну [7]. Так, кластерний аналіз згрупував локуси ризику за п'ятьма основними категоріями на основі їх зв'язку із цими безперервними глікемічними фенотипами. Перший кластер (PPARG, KLF14, IRS1, GCKR) характеризувався первинними ефектами на чутливість до інсуліну. Другий кластер (MTNR1B, 
GCK) містив алелі ризику, пов'язані зі зниженою секрецією інсуліну та гіперглікемією натще. ARAP1 становив третій кластер, що характеризувався деоректами в перетворенні інсуліну. Четвертий кластер (TCF7L2, SLC30A8, HHEX/ IDE, CDKAL1, CDKN2A/2B) був визначений локусами, що впливають на перетворення та секрецію інсуліну без помітних змін рівня глюкози натще. Кінцева група містила 20 локусів ризику без чітких зв'язків із безперервними глікемічними ознаками, які впливають на схильність до T2DM.

Кілька відтворюваних досліджень GWAS підтвердили встановлені гени сприйнятливості до T2DM у локусах SLC30A8, KCNQ1, CDC123, HNF1B, KCNJ11, TCF7L2, CDKAL1, CDKN2A/2B, PPARG, HHEX, IGF2BP2, GLIS3, JAZF1, WFS1 i MTNR1B у європейців та азіатів. Більшість виявлених локусів ризику сприйнятливості була поширена як серед східноазіатських країн, так і серед європейського населення, проте асоціації в цих спільних локусах, імовірно, є незалежними серед популяцій [8]. Такі відмінності у варіантах ризику між європейцями та східними азіатами, можливо, зумовлені різницею в генетичному тлі, частоті алелів ризику і характеристиках, таких, як особливості конституції тіла, харчування, культура та інші фрактори $[9,10]$, що обґрунтовує необхідність дослідження поліморфізму генів у кожній окремій популяції. Хоча під час досліджень GWAS серед багатоетнічних груп населення було виявлено численні локуси ризику T2DM, фрункціональний вплив цих локусів ризику все ще потрібно з'ясувати в різних популяціях.

Субстрат рецепторів інсуліну (IRS) $€$ ключовим центральним рецептором у передачі сигналів інсуліну. Виділено кілька поліморфрізмів IRS, проте заміна Gly на Arg 972 в IRS1, ймовірно, відіграє патогенетичну роль у розвитку T2DM [11]. Поліморфізм IRS1 G>A (p.Gly972Arg) сприяє інсулінорезистентності, послаблюючи здатність інсуліну активувати сигнальний шлях IRS1/ фоосфратидилінозитол-3-кінази/Akt/глікоген-синтази-кінази-3 в тканинах інсуліночутливих пацієнтів [12]. Коли інсулін зв'язується зі своїм рецептором на клітинній поверхні, IRS1, білок-ліганд стикування, фросфрорилюється і активує фросоратидилінозитол-3-кіназу. Це ініціює каскад внутрішньоклітинних сигналів, що призводить до різноманітних реакцій клітини. Однією з таких реакцій $є$ активація рецептора GLUT (транспорту глюкози), що зумовлює збільшення поглинання глюкози клітиною [13]. Пацієнти з Т2DМ мають знижену експресію та функцію IRS1 у жирових клітинах. Поліморфізм Gly972Arg є найбільш часто досліджуваним варіантом IRS1 [14]. Генотипи GA, GA+AA й алель А в дослідженні A. A. Yousef та співавт. показали значно вищу частоту розподілу в групі хворих на T2DM порівняно з контрольною групою з більшим ризиком розвитку T2DМ у здорових людей [11]. За результатами дослідження, поліморфізм генів IRS1 підвищує IP у пацієнтів з T2DM 3 тяжкою гіперглікемією. Тільки поліморфрізм гена IRS1 Gly972Arg впливає на IP у хворих на T2DM. Цей результат подібний до результатів досліджень S. A. El. Mkadem та співавт. [15], G. Villuendas та співавт. [16], J. Rung та співавт. [17], які виявили, що поліморфізм гена IRS1 ther.2963G>A (p.Gly972Arg) трапляється у пацієнтів з IP, і дані поліморфізми також впливають на IP. Було встановлено, що rs2943641 в IRS1 асоціюється 3 T2DM, IP та гіперінсулінемією у трьох європейських популяціях [18]. Літературні дані свідчать про те, що SNP Pro170Arg та Met209Thr у гені IRS1 також пов'язані зі зниженням активності фоссратидилінозитол-3-кінази, а згодом і з розвитком IP [19]. Крім того, автори відзначають, що поліморфізми Gly972Arg та Ala513Pro, які розташовані поблизу ділянок Tyr-Met-X-Met (YMXM) навколо Tyr987 і Tyr612, впливають на резистентність до інсуліну, гіперінсулінемію та жирнокислотний склад м'язів.

Наступним після IRS1 основним стикувальним протеїном, що міститься в клітинах, є IRS2 [20]. Він діє як резервний протеїн для внутрішньоклітинного розповсюдження сигналів інсуліну, включаючи активацію фоссратидилінозитол-3-кінази. Проте для активації IRS2 потрібна вища концентрація інсуліну. Gly1057Asp (G1057D) широко відомий варіант поліморфізму гена IRS2, за допомогою якого гліцин (G) замінюється аспартатом (D) у положенні 1057 [21].

Відомо, що хронічна гіперглікемія індукує диссрункцію мітохондрій, продукування кінцевих продуктів глікування та активацію шляхів протеїнкінази C, поліолу і гексозаміну, що в сукупності сприяє гіперпродукуванню активних форм оксигену й оксидативному стресу [22]. Активні форми оксигену зумовлюють ушкодження клітин у результаті пероксидного окиснення ліпідів, протеїнів та ушкодження ДНК. Ці окиснювальні ушкодження призводять до активації протеїну пухлини 53 (ТР53), який, у свою чергу, регулює експресію апоптотичних, прозапальних і метаболічних генів. Тому індуковані гіперглікемією TP53-опосередковані зміни експресії генів відіграють центральну роль у розвитку метаболічних порушень та судинних ускладнень діабету [23]. ТР53 - це фросфопротеїн, що складається з 393 амінокислот. У фрізіологічному стані ТР53 у клітинах зв'язаний з убіквітин-лігазою MDM2, яка інгібує його транскрипційну активність та сприяє його деградації. Однак генотоксичні агенти і стреси індукують фоссфорилювання протеїну 
TP53 та активізують його транскрипційну активність, що призводить або до зупинки росту, переважно у фразі G1/S, або до апоптозу і допомагає запобігти розвитку раку [24]. Також було продемонстровано, що активність ТР53, яка пригнічувала пухлину, пов'язана зі змінами метаболізму. Встановлено, що ТР53 пригнічує гліколіз і сприяє окисному фосорорилюванню у відповідь на голодування та гіпоксію [25]. 3 огляду на те, що ТР53 індукує зміни метаболізму у відповідь на різні стреси, включаючи окиснювальний, було висунуто припущення, що цей протеїн може відігравати значну роль при метаболічних захворюваннях, таких, як діабет та ожиріння [26].

Патогенез IP і T2DM пов'язаний із субклінічним хронічним запаленням та активацією імунної системи; однак, що викликає це запалення, досі незрозуміло [27]. Генетичні поліморфізми інтерлейкінів (IL) тісно пов'язані з їх діяльністю, мабуть, через зміну фрункції цитокінів або порушення регулювання їх експресії. Деякі дослідники вивчали зв'язок поліморфізмів генів TNFa, IL6 та IL10 з метаболічними захворюваннями [2830]. Незважаючи на дослідження зв'язку маркерів запалення та SNP у генах цитокінів, залишається багато суперечливих питань щодо їх ролі у виникненні діабету [31-34]. Варто відмітити, що кількість генів, які підвищують сприйнятливість до T2DM, величезна. Одним 3 таких генів $€ \mathrm{TNF}$, який кодує протеїн TNFa. Ця молекула складається із 157 амінокислот, розташованих у хромосомі 6. Даний цитокін бере участь у запаленні, апоптозі, інфекціях та ракових процесах [35]. Описано 2 поліморфізми в промоторній ділянці гена TNF, один присутній у положенні -308 [36]. У зв'язку з цим, J. J. Swaroop та співавт. [37] продемонстрували зв'язок між адипоцитокіном TNFa та розвитком IP. G. I. Luna та співавт. у своєму огляді підсумували, що вплив генетичних поліморфізмів TNF на певні захворювання може виявлятись в одній популяції, але не в іншій, це може вплинути на частоту та розподіл даного поліморфізму в окремій популяції. Різниця у впливі може бути зумовлена як расовими варіаціями, так і іншими фракторами [38]. H. Sefri та співавт. [39] у своєму мета-аналізі вказують на відсутність статистично значимої асоціації між поліморфізмом у досліджуваній ділянці гена TNF та ризиком розвитку T2DM, що узгоджується 3 дослідженням R.-N. Feng та співавт. [40].

Гени IL1 (IL1 $\alpha,-\beta$ та -Ra) розташовані в хромосомі 2q12-21. IL1 $\beta$ та IL1Ra відіграють важливу роль у реконструкції тканин, є потужними медіаторами хронічного запалення [41] і, отже, беруть участь у патогенезі T2DM та супутніх ускладнень [42]. IL4 також відіграє вирішальну роль у патофрізіології T2DM [43]. Гетеродимеризація $\alpha$-ланцюга трансмембранного рецептора з високою спорідненістю (IL4R $\alpha$ ) опосередковується IL4 у послідовному каскаді. Було виявлено кілька генів-кандидатів, включаючи ген IL4Ra, який розміщений у хромосомі 16p. IL1Ra та IL4 є основними протизапальними цитокінами [44] i беруть участь у патофрізіологічних процесах, які спричиняють T2DM. IL6 секретують імунні клітини, жирова тканина та м'язи, і він здатний прискорювати або гальмувати запальні процеси. IL6 може прямо впливати на гомеостаз глюкози і метаболізм або діє опосередковано, впливаючи на адипоцити, $\beta$-клітини підшлункової залози тощо [45]. У людини ген IL6 відображається в хромосомі 7p15-р21. Встановлено, що експресія MPHK IL6 та резистентність до інсуліну мають значну кореляцію і підвищують концентрацію IL6 у плазмі крові з вищим ризиком розвитку T2DM, що робить його геном-кандидатом. SNP-промотори IL6 розглядають як фактори ризику розвитку T2DM [46].

IL10 є важливим протизапальним цитокіном, який відіграє вирішальну роль як модулятор імунної відповіді. Кодуючий ген IL10 розташований у хромосомі 1 (1q31-1q32) [47], a IL10 продукують активовані Т-клітини, В-клітини, моноцити та макрофаги, i, за оцінками, 75 \% варіації його продукції генетично детерміновані [48-50]. За результатами дослідження, рівень IL10 був нижчим у пацієнтів з порушеннями толерантності до глюкози або T2DM порівняно з пацієнтами з нормальною толерантністю до глюкози та показав зворотну кореляцію з ІМТ [51]. І навпаки, A. Al-Shukaili та колеги [52] виявили більший рівень IL10 у пацієнтів з T2DM порівняно $з$ контролем. У сукупності незрозуміло, чи підвищений рівень IL10 забезпечує захист від розвитку T2DM за рахунок зменшення продукції прозапальних цитокінів або підвищення рівня IL10 при T2DM призводить до компенсаторної реакції проти зростання рівня протизапальних медіаторів, насамперед TNF $\alpha$ та IL6 [27].

Продукція IL10 асоційована з генетичними варіаціями в його промоторній ділянці, яка контролює транскрипцію і містить SNP, що пов'язані з Т2DМ та його ускладненнями $[53,54]$. Поліморфні ділянки в межах промоторної ділянки IL10 включають кілька SNP [rs1800896 (-1082 A / G), rs1800871 (-819 T / C) тa rs1800872 (-592 A / C)], які асоціюються з розвитком T2DM, а також 2 мікросателітних локуси безпосередньо перед місцем ініціювання транскрипційного IL10 [55]. Дослідження in vitro з використанням мононуклеарів перифреричної крові дозволяють припустити, що алелі $-1082 \mathrm{G},-819 \mathrm{C}$ та $-592 \mathrm{C}$ пов'язані 3 вищим рівнем продукції IL10 [56]. Взаємозв'язок 
між SNP -1082 A / G та -592 A / C і T2DM було виявлено в кількох етнічних групах [57-59]. Крім того, в цих трьох поліморфнних ділянках також виявлено асоціацію 3 нефропатією при T2DM [54]. В мета-аналізі F. Zhang було встановлено, що існує зв'язок між поліморфізмом гена IL10 -1082 G / A i T2DM, але не виявлено зв'язку для -819 Т / C або -592 A / C [60].

Основним фактором ризику розвитку T2DM $€$ ожиріння, a IP існує і при ожирінні [61]. Загальногеномні дослідження щодо IMT, співвідношення окружності талії і стегон та інших ознак ожиріння виявили понад 300 SNP [62-64]. Визначення причинного гена/варіанта в локусах залишається основною проблемою. Наприклад, упродовж останніх 10 років локус FTO (fat mass and obesity-associated protein - протеїн, який кодується однойменним геном, розташованим у людей на короткому плечі хромосоми 16) досліджували дуже детально [65], але механізми, за допомогою яких він впливає на масу тіла, досі не до кінця вивчено. Сучасні дослідження показують велику кількість механізмів у різних тканинах, які пов'язують локус FTO і масу тіла [66, 67]. щораз більше ідентифрікованих GWAS локусів проходять поглиблений аналіз для з'ясування їх біології у розвитку ожиріння (TMEM18 [68, 69], CADM2 [70], LYPLAL1 [71], ADCY3 [72]), але багато ще не досліджено.

Жирова тканина $є$ ендокринним органом, який спільно регулює обмін речовин у всьому організмі й здатний виробляти різноманітні цитокіни (TNFa, IL6, IL1ß) та інші біоактивні продукти, такі, як лептин, резистин і моноцитарний хемоатрактантний протеїн-1 (MCP-1/CCL2) [73, 74]. Жирова тканина в людей з ожирінням характеризується наявністю прозапальних імунних клітин (CD8 + Т-лімсоцитів, клітин IFN-y + Th1, В-клітин, опасистих клітин, нейтрофрілів та макрофрагів), активованих хемокінами, що виділяються зі стресових адипоцитів у відповідь на перевантаження ліпідів [75]. TNF 308 G>A впливає на експресію гена, збільшуючи експресію даного цитокіну в жировій тканині (модулятор цього гена). Алель даного гена частіше трапляється в дітей, які страждають від ожиріння; отже, це найбільш в ивчений генний поліморфізм [76]. E. Arner та співавт., спостерігаючи жінок у пременопаузі, показали позитивну залежність між секрецією TNFa та IMT, загальним вмістом жиру в організмі й об'ємом адипоцитів, при цьому концентрація TNF $\alpha$ зростала у пацієнтів 3 жировою гіпертрофрією і знижувалася в осіб 3 жировою гіперплазією [77]. Встановлено, що TNFa в худих жінок у пременопаузі відіграє важливу роль у визначенні загальної маси і маси жирової тканини, регулюючи адипогенез або відкладаючи ліпіди в адипоцитах. На цій підставі інші дослідники намагалися встановити зв'язок між полімо р фізмами TNFa та ожирінням або ступенем надмірної маси тіла, зокрема, W. T. Chang довів, що поліморфрізм TNF 308 G>A пов'язаний з ожирінням [78].

При пошуку літературних джерел щодо спільного генетичного підірунтя Т2DM і хронічного панкреатиту (СР) встановлено, що поєднання T2DM+CP можуть зумовлювати генетичні варіанти T2DM [79]. Учені виявили, що особи 3 T2DM+CP частіше страждають від надмірної маси тіла або ожиріння та мають сімейний анамнез цукров ого діабету порівняно з тими, хто страждає від СР та не має діабету [80]. Також було встановлено, що специфрічні для підшлункової залози фактори, включаючи екзокринну недостатність, атрофію, кальцифрікацію, частіше трапляються у хворих з поєднаним перебігом T2DM+CP, ніж при CP без діабету. Як T2DM+CP можна концептуалізувати в рамках патофізіології T2DM? B основі T2DM лежать 2 ключові особливості: резистентність до інсуліну та недостатня компенса торна гіперінсулінемія. Більшість людей з IP реагує компенсаторним збільшенням продукції бета-клітин, які підвищують рівень циркулюючого інсуліну для подолання тканинної резистентності до інсуліну та підтримки нормоглікемії. У тих осіб, які не можуть витримати цю гіперінсулінемічну компенсацію, розвиваються порушення толерантності до глюкози і, зрештою, T2DM [81]. Механізми, що лежать в основі бета-клітинної недостатності при типовому T2DM, $€$ багатофракторними [82]. При Т2DM+CP поглиблюється диссуункція бета-клітин унаслідок хронічного запалення та фріброзу підшлункової залози, що, ймовірно, сприяє загибелі бета-клітин і нездатності компенсувати резистентність до інсуліну, це поглиблює перебіг діабету та панкреатиту [83]. Генетичне зіставлення T2DM+CP та T2DM за SNP, які асоціюються з T2DM відповідно до GWAS, не відображає загальної ролі генетики, яку можна було б очікувати від послідовності цілого генома і всебічного аналізу всіх відомих генетичних варіантів, пов'язаних зі складною патобіол огією захворювань підшлункової залози та/або діабету [79, 84].

Велика кількість досліджень дає підстави сподіватися, що в майбутньому дослідження генетики цукрового діабету за умови його коморбідного перебігу дозволять розробити ефективні профрілактичні й терапевтичні засоби лікування, проте на даний час необхідно детально вивчити роль полімор фріз м ів різних генів, особливо тих, що мають значення в патогенезі кожного окремого захворювання, у сприйнятливості до коморбідного перебігу цукрового діабету 2 типу. 


\section{СПИСОК ЛІТЕРАТУРИ}

1. Identifying Candidate Genes for Type 2 Diabetes Mellitus and Obesity through Gene Expression Profiling in Multiple Tissues or Cells / J. Chen, Y. Meng, J. Zhou [et al.] // J Diabetes Res. - 2003. - 2003. - P. 1-9.

2. Large-scale association analysis provides insights into the genetic architecture and pathophysiology of type 2 diabetes / A.P. Morris, B.F. Voight, T.M. Teslovich [et al.] // Nat Genet. - 2012. - 44, - No. 9. - P. 981-990.

3. Flannick J. Type 2 diabetes: genetic data sharing to advance complex disease research / J. Flannick, J. C. Florez // Nat. Rev. Genet. - 2016. - 17, - No. 9. P. 535-549.

4. Twelve type 2 diabetes susceptibility loci identified through large-scale association analysis / B. F. Voight, L. J. Scott, V. Steinthorsdottir [et al.] // Nat Genet. 2010. - 42, No. 9. - P. 579-589.

5. A genome-wide association study in the Japanese population identifies susceptibility loci for type 2 diabetes at UBE2E 2 and C2CD4A-C2CD4B / T. Yamauchi, K. Hara, S. Maeda [ et al.] // Nat. Genet. - 2010. - 42, No. 10. - P. 864-868.

6. Florez J. C. Newly identified loci highlight beta cell dysfunction as a key cause of type 2 diabetes: where are the insulin resistance genes / J. C. Florez // Diabetologia. - 2008. - 51. - P.1100-1110.

7. Impact of type 2 diabetes susceptibility variants on quantitative glycemic traits reveals mechanistic heterogeneity / A. S. Dimas, V. Lagou, A. Barker [et al.] // Diabetes. - 2014. - 63. - P. 2158-2171.

8. Impact of KCNQ1, CDKN2A/2B, CDKAL1, HHEX, MTNR1B, SLC3OA8, TCF7L2, and UBE2E2 on risk of developing type 2 diabetes in Thai population / N. Plengvidhya, C. Chanprasert, N. Chongjaroen [et al.] // BMC Med. Genet. - 2018. - 19. - P. 93.

9. SNPs in KCNQ1 are associated with susceptibility to type 2 diabetes in east Asian and European populations / H. Unoki, A. Takahashi, T. Kawaguchi [et al.] // Nat. Genet. - 2008. - 40, No. 9. - P. 1098-1102.

10. Variants in KCNQ1 are associated with susceptibility to type 2 diabetes mellitus / K. Yasuda, K. Miyake, Y. Horikawa [et al.] // Nat. Genet. - 2008. - 40, No. 9. P. 1092-1097.

11. Genetic polymorphism (r.2963G>A) in type 2 diabetes mellitus patients associated with insulin resistance / A. A. Yousef, E. G. Behiry, W. M. A. Allah [et al.] // Appl. Clin. Genet. - 2018. - 28, No. 11. - P. 99-106. DOI: 10.2147/TACG.S171096. PMID: 30319284; PMCID: PMC6167972.

12. Erica Oberg. Type 2 diabetes diet plan: List of foods to eat and avoid / Erica Oberg // ND. - 2018.

13. The combined role of allelic variants of IRS-1 and IRS-2 genes in susceptibility to type 2 diabetes in the Punjabi Pakistani subjects / A. ljaz, S. Babar, S. Sarwar [et al.] // Diabetol. Metab. Syndr. - 2019. - 11. P. 64. - Access mode :https://doi.org/10.1186/s13098019-0459-1

14. Association of IRS1 genetic variants with glucose control and insulin resistance in type 2 diabetic patients from Bosnia and Herzegovina / L. Mahmutovic, T. Bego, M. Sterner [et al.] // Drug Metab. Personal Ther. - 2019. 34, No. 1. - P. 20180031.

15. Role of allelic variants Gly972Arg of IRS-1 and Gly1057 Asp of IRS-2 in moderate-to-severe insulin resistance of women with polycystic ovary syndrome /
S. A. El Mkadem, C. Lautier, F. Macari [et al.]// Diabetes. 2001. - 50, No. 9. - P. 2164-2168.

16. Polymorphisms in the insulin receptor substrate-1 (IRS-1) gene and the insulin receptor substrate-2 (IRS-2) gene in fluence glucose homeostasis and body mass index in women with polycystic ovary syndrome and nonhyperandrogenic controls / G. Villuendas, J. I. BotellaCarretero, B. Roldán [et al.] // Hum. Reprod. -2005. - 20, No. 11. - P. 3184-3191.

17. Genetic variant near IRS1 is associated with type 2 diabetes, insulin resistance and hyperinsulinemia / J. Rung, S. Cauchi, A. Albrechtsen [et al.] // Nat. Genet. 2009. - 41, No.10. - P. 1110-1115.

18. Ide ntification of new genetic risk variants for type 2 diabetes / X. O. Shu, J. Long, Q. Cai [et al.] // PLoS Genet. - 2010. - 6, No. 9. - 1001127.

19. Iscioglu IRS1 gene polymorphisms Gly972Arg and Ala513Pro are not associated with insulin resistance and type 2 diabetes risk in non-obese Turkish population / Hilal Arikoglu, Melda Aksoy, Hepdogru Dudu [et al.] // Meta Gene. - 2014. - 2. - P. 579-585.

20. PGC1A regulates the IRS1: IRS2 ratio during fasting to influence hepatic metabolism downstream of insulin / A. Besse-Patin, S. Jeromson, P. LevesqueDamphousse [et al.] // Proc. Natl. Acad. Sci. -2019. - 116, No. 10. - P. 4285-4290.

21. Diabetes mellitus types: key genetic determinants and risk assessment / D. R. Vana, D. Adapa, V. Prasad [et al.] // Genet. Mol. Res. - 2019.

22. Tumour protein 53 is linked with type 2 diabetes mellitus / A. Sliwinska, J. Kasznicki, M. Kosmalski [et al.] // Indian J. Med. Res. - 2017. - 146, No. 2. - P. 237-243. DOI:10.4103/ijmr.IJMR_1401_15

23. Hyperglycemia-induced oxidative stress and its role in diabetes mellitus related cardiovascular diseases / T. V. Fiorentino, A. Prioletta, P. Zuo [et al.] // Current Pharmaceutical Design. -2013. - 19, No. 32. - P. 5695-5703.

24. Vousden K. H. Blinded by the light: The growing Complexity of p53 / K. H. Vousden, C. Prives // Cell. 2009. - 137, No. 3. - P. 413-431.

25. Jones R. G. Tumor suppressors and cell metabolism: a recipe for cancer growth / R. G. Jones, C. B. Thompson // Genes Dev. - 2009. - 23, No. 5. P. 537-548.

26. Kung C. P. The role of the p53 tumor suppressor in metabolism and diabetes / C. P. Kung, M. E. Murphy // J. Endocrinol. - 2016. - 231, No. 2. - P. 61-75. DOI:10.1530/JOE-16-0324.

27. IL-6, TNF- $\alpha$, and IL-10 levels/ polymorphisms and their association with type 2 diabetes mellitus and obesity in Brazilian individuals / Kathryna Fontana Rodrigues, Nathalia Teixeira Pietrani, Adriana Aparecida Bosco [et al.] // Arch. Endocrinol. Metab. - 2017. - 61, No. 5. - P. 438-446.

28. Large-scale association analysis of TNF/LTA gene region polymorphisms in type 2 diabetes / V. I. Boraska, N. W. Rayner, C. J. B. Groves [ et al. ] // BMC Med. Genet. - 2010. - 11. - P. 69.

29. Saxena M. Association of IL-6, TNF- $\alpha$ and IL-10 gene polymorphisms with type 2 diabetes mellitus / M. Saxena, N. Srivastava, M. Banerjee // Mol. Biol. Rep. 2013. - 40, No.11. - P. 6271-6279.

30. Interleukin-10 (-1082G/A) gene polymorphism in patients with type 2 diabetes with and without nephropa- 
thy / M. Erdogan, S. Cetinkalp, A. G. Ozgen [et al.] // Genet. Te st Mol. Biomarkers. - 2012. - 16, No. 2. P. 91-94.

31. The TNF-alpha -308G/A polymorphism is associated with type 2 diabetes mellitus: an updated metaanalysis / Y. Zhao, Z. Li, L. Zhang [et al.] // Mol. Biol. Rep. - 2014. - 41, No. 1. - P. 73-83.

32. Association of TNF- $\alpha 308 \mathrm{G} / \mathrm{A}$ polymorphism with type 2 diabetes: a case-control study in the Iranian Kurdish Ethnic Group / H. Golshani, K. Haghani, M. Dousti [et al.] // Osong Public Health Res. Perspect. -2015. - 6, No. 2. - P. 94-99.

33. Association between interleukin 10 gene- 1082 A/G polymorphism and the risk of type 2 diabetes mellitus: a meta-analysis of 4250 subjects / Y. W. Yin, A. M. Hu, Q. Q. Sun [et al.] // Cytokine. - 2013. - 62, No. 2. P. 226-231.

34. Association between interleukin-10 gene -592 C/A polymorphism and the risk of type 2 diabetes mellitus: a meta-analysis of 5320 subjects / Y. W. Yin, Q. Q. Sun, B. B. Zhang [et al.] // Hum. Immunol. - 2012. - 73, No. 9. P. 960-965.

35. Tumor necrosis factor a regulates endothelial progenitor cell migration via CADM1 and NF-KB / A. R. Prisco, B. R. Hoffmann, C. C. Kaczorowski [et al.] // Stem Cells. - 2016. - 34, No. 7. - P. 1922-1933.

36. A polymorphism in the promoter of the tumor necrosis factor- $\alpha$ gene $(-308)$ is associated with coronary heart disease in type 2 diabetic patients / J. Vendrell, J.-M. Fernandez-Real, C. Gutierrez [et al.] // Atherosclerosis. - 2003. - 167, No. 2. - P. 257-264.

37. Swaroop J. J. Association of TNF- $\alpha$ with insulin resistance in type 2 diabetes mellitus / J. J. Swaroop, D. Rajarajeswari, J. Naidu // The Indian Journal of Medical Research. - 2012. - 135, No. 1. - P. 127.

38. Geisa Izetti Luna. Association between -308G/A TNFA Polymorphism and susceptibility to type 2 diabetes mellitus: A systematic review / Geisa Izetti Luna, Izabel Cristina Rodrigues da Silva, Mauro Niskier Sanchez // Journal of Diabetes Research. - 2016. - 2016. P. 6. Access mode :https://doi.org/10.1155/2016/6309484

39. TNF A -308G>A polymorphism in Moroccan patients with type 2 diabetes mellitus: a case-control study and meta-analysis / H. Sefri, H. Benrahma, H. Charoute [et al.] // Molecular Biology Reports. - 2014. -41, No. 9. P. 5805-5811.

40. Meta-analysis of TNF $308 \mathrm{G} / \mathrm{A}$ polymorphism and type 2 diabetes mellitus / R.-N. Feng, C. Zhao, C.-H. Sun [et al.] // PLoS ONE. - 2011. - 6, No. 4. - P. 18480.

41. The human IL-1 receptor antagonist gene (IL1RN) maps to chromosome 2q14-q21, in the region of the IL-1 alpha and IL-1 beta loci / A. Steinkasserer, N. K. Spurr, S. Cox [et al.] // Genomics. - 1992. - 13. P. 654-657.

42. Banerjee M. Interleukin-1 (IL-1) family of cytokines: role in type 2 diabetes / M. Banerjee, M. Saxena // Clin. Chim. Acta. - 2012. - 413. - P. 1163-1170.

43. Hülsmeyer M. Structure of interleukin 4 mutant E9A suggests polar steering in receptor-complex formation / M. Hülsmeyer, C. Scheufler, M. K. Dreyer // Acta Crystallogr. D Biol. Crystallogr. - 2001. - 57. - P. 13341336.

44. Dinarello C. A. Biologic basis for interleukin-1 in disease / C. A. Dinarello // Blood. -1996. - 87. - P. 20952147.
45. Banerjee M. Genetic polymorphisms of cytokine genes in type 2 diabetes mellitus / M. Banerjee, M. Saxena // World Journal of Diabetes. - 2014. - 5, No. 4. P. 493-504. DOI: 10.4239/wjd.v5.i4.493.

46. C-174G polymorphism in the promoter of the interleukin- 6 gene is associated with insulin resistance / M. Cardellini, L. Perego, M. D'Adamo [et al.] // Diabetes Care. - 2005. - 28. - P. 2007-2012.

47. Mapping of the human IL10 gene and further characterization of the $5^{\prime}$ flanking sequence / J. Eskdale, D. Kube, H. Tesch [et al.] // Immunogenetics. - 1997. 46, No. 2. - P. 120-128.

48. An interleukin-10 gene polymorphism associated with the development of cervical lesions in women infected with Human Papillomavirus and using oral contraceptives / B. S.Chagas, A. P. Gurgel, H. L. da Cruz [et al.] // Infect. Genet. Evol. - 2013. - 19. - P. 32-37.

49. Interleukin-10 promoter variants predict HPVpositive tumors and survival of squamous cell carcinoma of the oropharynx / L. Jin, E. M. Sturgis, X. Cao [et al.] // FASEB J. - 2013. - 27, No. 6. - P. 2496-2503.

50 . Variants of the interleukin-10 promoter gene are associated with obesity and insulin resistance but not type 2 diabetes in caucasian italian subjects / D. Scarpelli, M. Cardellini, F. Andreozzi [et al.] // Diabetes. - 2006. 55, No. 5. - P. 1529-533.

51. Association of interleukin-6, C-reactive protein, interleukin-10 and adiponectin plasma concentrations with measures of obesity, insulin sensitivity and glucose metabolism / M. Blüher, M. Fasshauer, A. Tönjes [et al.] // Exp. Clin. Endocrinol. Diabetes. - 2005. - 113, No. 9. P. 534-537.

52. Analysis of inflammatory mediators in type 2 diabetes patients / A. Al-Shukaili, S. Al-Ghafri, S. AlMarhoobi [et al.] // Int. J. Endocrinol. - 2013. P. 976810.

53. Study of interleukin-10 promoter region polymorphisms (-1082A/G, -819T/C and $-592 \mathrm{~A} / \mathrm{C})$ in type 1 diabetes mellitus in Turkish population / $\mathrm{H}$. Mohebbatikaljahi, S. Menevse, I. Yetkin [et al.] // Demirci H. J. Genet. - 2009. - 88, No. 2. - 245-248.

54. Association of Interleukin-10 (-592A/C) gene polymorphism with its level in type 2 diabetes mellitus with and without nephropathy / A. A. Mahmoud, A. Sheneef, A. A. Sayed [et al.] // J. Mol. Genet. Med. - 2016. 10. - P. 199.

55. Novel Interleukin-10 gene polymorphism is linked to gestational diabetes in Taiwanese population / J. Kang, C. H. Liu, C. N. Lee [ et al. ] // Front Genet. - 2019. 18, No. 10. - P. 89.

56. Interleukin-10 promoter polymorphism predicts initial response of chronic hepatitis $C$ to interferon alfa / C. J. Edwards-Smith, J. R. Jonsson, D. M. Purdie [et al.] // Hepatology. - 1999. - 30, No. 2. - P. 526-530.

57. Association of IL-10 and IL-6 gene polymorphisms with type 2 diabetes mellitus among Egyptian patients / M. A. H. Helaly, E. S. Z. Hatata, M. Abu-Elmagd [et al.] // Eur. J. General Med. - 2013. - 10. - P. 158-162. 10.29333/ejgm/82250

58. Saxena M. Association of IL-6, TNF- $\alpha$ and IL-10 gene polymorphisms with type 2 diabetes mellitus / $\mathrm{M}$. Saxena, N. Srivastava, M. Banerjee // Mol. Biol. Rep. 2013. - 40, No. 11. - P. 6271-6279.

59. Association between interleukin 10 gene polymorphisms and risk of type 2 diabetes mellitus in a 
Chinese population / H. Bai, D. Jing, A. Guo [et al.] // J. Int. Med. Res. - 2014. - 42, No. 3. - P. 702-710.

60. Zhang F. A meta-analysis about the association between-1082G/A and-819C/T polymorphisms of IL-10 gene and risk of type 2 diabetes / F. Zhang, Y. Yang, H. Lei // Hum. Immunol. - 2013. - 74. - P. 618-626.

61. Identifying candidate genes for type 2 diabetes mellitus and obesity through gene expression profiling in multiple tissues or cells / Junhui Chen, Yuhuan Meng Jinghui Zhou [et al.] // Journal of Diabetes Research. 2013. - 2013. - P. 9. ID 970435. -Access mode : https:// doi.org/10.1155/2013/970435

62. Genetic studies of body mass index yield new insights for obesity biology / A. E. Locke, B. Kahali, S. I. Berndt [et al.] // Nature. - 2015. - 518, No. 7538. P. 197-206.

63. New genetic loci link adipose and insulin biology to body fat distribution / D. Shungin, T. W. Winkler D. C. Croteau-Chonka [et al.] // Nature. - 2015. - 518, No. 7538. - P. 187-196.

64. Genome-wide association study identifies 112 new loci for body mass index in the japanese population / M. Akiyama, Y. Okada, M. Kanai [et al.] // Nat. Genet. 2017. - 49, No. 10. - P. 1458-1467.

65. Obesity and fto: Changing focus at a complex locus / Y. C. Tung, G. S. Yeo, S. O'Rahilly [et al.] // Cell Metab. - 2014. - 20. - No. 5. - P. 710-718.

66 . Fto obesity variant circuitry and adipocyte browning in humans / M. Claussnitzer, S. N. Dankel, K. H. Kim [et al.] // N. Engl. J. Med. -2015. - 373, No. 10. - P. 895907.

67. Hypomorphism of fto and rpgrip1l causes obesity in mice / G. Stratigopoulos, L. C. Burnett, R. Rausch [et al.] // J. Clin. Invest. -2016. -126, No. 5. - P.1897-1910.

68. Obesity-associated gene tmem18 has a role in the central control of appetite and body weight regulation / R. Larder, M. F. M. Sim, P. Gulati [et al.] // Proc. Natl. Acad. Sci. U SA. - 2017. - 114, No. 35. - P. 9421-9426.

69 . The drosophila ortholog of tmem18 regulates insulin and glucagon-like signaling / L. Wiemerslage, P. A. Gohel, G. J. Maestri [et al.] // Endocrinol. - 2016. 229, No. 3. - P. 233-243.

70. Regulation of body weight and energy homeostasis by neuronal cell adhesion molecule 1 / T. Rathjen, X. Yan, N. L. Kononenko [et al.] // Nat. Neurosci. -2017. 20, No. 8. - P. 1096-1103.

71. Lyplal1 is dispensable for normal fat deposition in mice / R. A. Watson, A. S. Gates, E. H. Wynn [et al.] // Disease Models \& Mechanisms. - 2017.

72. Subcellular localization of mc4r with adcy3 at neuronal primary cilia underlies a common pathway for genetic predisposition to obesity / J. E. Siljee, Y. Wang, A. A. Bernard [et al.] // Nat. Genet. - 2018.

\section{REFERENCES}

1. Junhui, Chen, Yuhuan, Meng, Jinghui, Zhou, Min, Zhuo, Fei, Ling, Yu, Zhang, Hongli, Du, Xiaoning, Wang. (2013). "Identifying candidate genes for type 2 diabetes mellitus and obesity through gene expression profiling in multiple tissues or cells". Journal of Diabetes Research, Article ID 970435, 9. Retrieved from: https://doi. org/10.1155/2013/970435.

2. Morris, A.P., Voight, B.F., \& Teslovich, T.M. (2012). Large-scale association analysis provides insights into
73. $\mathrm{Xu} \mathrm{H}$. Obesity and metabolic inflammation / H. Xu // Drug Discov. Today Dis. Mech. - 2013. - 10, No. 1-2. - P. 21-25.

74. Hotamisligil G. S. Inflammation and metabolic disorders / G. S. Hotamisligil // Nature. - 2006. - 444, No. 7121. - P. 860-867.

75. Sun K. Adipose tissue remodeling and obesity / K. Sun, C. M. Kusminski, P. E.Scherer // J. Clin. Invest. 2011. - 121, No. 6. - P. 2094-2101.

76. The impact of TNF-a308G $>$ Agene polymorphism on children's overweight riskand an assessment of biochemical variables: A cross-sectional single-center experience / Cristina Oana Margineana, Claudiu Marginean, Mihaela lancuc [et al.] // Pediatrics and Neonatology. 2019. - 60. - P. 19-27.

77. Arner E. Tumor necrosis factor alpha and regulation of adipose tissue / E. Arner, M. Ryde'n, P. Arner // N. Engl. J. Med. - 2010. - 362. - P. 1151e3.

78. The $-308 \mathrm{G} / \mathrm{A}$ of tumor necrosis factor (TNF)-a and $825 \mathrm{C} / \mathrm{t}$ of guanidine nucleotide binding protein 3 (GNB3) are associated with the onset of acute myocardial infarction and obesity in Taiwan / W. T. Chang, Y. C. Wang, C. C. Chen [et al.] // Int. J. Mol. Sci. - 2012. - 13. P. $1846 \mathrm{e} 57$.

79. Consortium for the Study of Chronic Pancreatitis, Diabetes, and Pancreatic Cancer (CPDPC). Genetic risk score in diabetes associated with chronic pancreatitis versus type 2 diabetes mellitus / M. O. Goodarzi, T. Nagpal, P. Greer [et al.] // Clin. Transl. Gastroenterol. -2019. 10, No. 7. - P. 00057.

80. Patient and disease characteristics associated with the presence of diabetes mellitus in adults with chronic pancreatitis in the United States / M. D. Bellin, D. C. Whitcomb, J. Abberbock [ et al. ] // Am. J. Gastroenterol. - 2017. - 112. - P. 1457-1465.

81. Beta-cell dysfunction and glucose intolerance: Results from the San Antonio Metabolism (SAM) study I A. Gastaldelli, E. Ferrannini, Y. Miyazaki [et al.] // Diabetologia. - 2004. - 47. - P. 31-39.

82. Chunguang Chen. Human beta cell mass and function in diabetes: Recent advances in knowledge and technologies to understand disease pathogenesis I Chunguang Chen, Christian M. Cohrs, Julia Stertmann [et al.] // Mol Metab. - 2017. - 6. - P. 943-957.

83. Beta-cell dysfunction in chronic pancreatitis / M. Sasikala, R. Talukdar, P. Pavan kumar [ et al.] // Dig. Dis. Sci. - 2012. - 57. - P.1764-1772.

84. Fine-mapping type 2 diabetes loci to singlevariant resolution using high-density imputation and islet-specific epigenome maps / A. Mahajan, D. Taliun, M. Thurner [et al.] // Nat. Genet. - 2018. - 50. - P. 15051513.

the genetic architecture and pathophysiology of type 2 diabetes. Nat Genet., 44, 981-990.

3. Flannick, J., \& Florez, J.C. (2016). Type 2 diabetes: genetic data sharing to advance complex disease research. Nat. Rev. Genet., 17, 535-549.

4. Voight, B.F., Scott, L.J., Steinthorsdottir, V., Morris, A.P., Dina, C., Welch, R.P., et al. (2010). Twelve type 2 diabetes susceptibility loci identified through large-scale association analysis. Nat Genet., 42 (7), 579-589. 
5. Yamauchi, T., Hara, K., Maeda, S., Yasuda, K., Takahashi, A., Horikoshi, M., et al. (2010). A genome-wide association study in the Japanese population identifies susceptibility loci for type 2 diabetes at UBE2E2 and C2CD4A-C2CD4B. Nat. Genet., 42 (10), 864-868.

6. Florez, J.C. (2008). Newly identified loci highlight beta cell dysfunction as a key cause of type 2 diabetes: where are the insulin resistance genes? Diabetologia, 51, 1100-1110.

7. Dimas, A.S., Lagou, V., \& Barker, A. (2014). Impact of type 2 diabetes susceptibility variants on quantitative glycemic traits reveals mechanistic heterogeneity. Diabetes, 63, 2158-2171.

8. Plengvidhya, N., Chanprasert, C., \& Chongjaroen, N., (2018). Impact of KCNQ1, CDKN2A/2B, CDKAL1, HHEX, MTNR1B, SLC3OA8, TCF7L2, and UBE2E2 on risk of developing type 2 diabetes in Thai population. $B M C$ Med. Genet ., 19, 93.

9. Unoki, H., Takahashi, A., Kawaguchi, T., Hara, K., Horikoshi, M., Andersen, G., et al. (2008). SNPs in KCNQ1 are associated with susceptibility to type 2 diabetes in East Asian and European populations. Nat. Genet., 40 (9), 1098-1102.

10. Yasuda, K., Miyake, K., Horikawa, Y., Hara, K., Osawa, H., Furuta, H., et al. (2008). Variants in KCNQ1 are associated with susceptibility to type 2 diabetes mellitus. Nat Genet., 40 (9), 1092-1097.

11. Yousef, A.A., Behiry, E.G., Allah, W.M.A., Hussien, A.M., Abdelmoneam, A.A., Imam, M.H., \& Hikal, D.M. (2018). IRS-1 genetic polymorphism (r.2963G>A) in type 2 diabetes mellitus patients associated with insulin resistance. Appl. Clin. Genet., 28 (11), 99-106. DOI: 10.2147/TACG.S171096. PMID: 30319284; PMCID: PMC6167972.

12. Erica Oberg, N.D. (2018). Type 2 diabetes diet plan: List of foods to eat and avoid.

13. ljaz, A., Babar, S., \& Sarwar, S. (2019). The combined role of allelic variants of IRS-1 and IRS-2genes in susceptibility to type 2 diabetes in the Punjabi Pakistani subjects. Diabetol. Metab. Syndr., 11, 64. Retrieved from: https://doi.org/10.1186/s13098-019-0459-1

14. Mahmutovic, L., Bego, T., \& Sterner, M., (2019). Association of IRS1 genetic variants with glucose control and insulin resistance in type 2 diabetic patients from Bosnia and Herzegovina. Drug Metab Personal Ther.

15. El, Mkadem, S.A., Lautier, C., \& Macari, F., (2001). Role of allelic variants Gly972Arg of IRS-1 and Gly1057Asp of IRS-2 in moderate-to-severe insulin resistance of women with polycystic ovary syndrome. Diabetes, 50 (9), 2164-2168.

16. Villuendas, G., Botella-Carretero, J.I., Roldán, B., Sancho, J., Escobar-Morreale, H.F., \& San Millán, J.L. (2005). Polymorphisms in the insulin receptor substrate-1 (IRS-1) gene and the insulin receptor substrate-2 (IRS-2) gene influence glucose homeostasis and body mass index in women with polycystic ovary syndrome and nonhyperandrogenic controls. Hum. Reprod., 20 (11), 31843191.

17. Rung, J., Cauchi, S., \& Albrechtsen., A. (2009). Genetic variant near IRS1 is associated with type 2 diabetes, insulin resistance and hyperinsulinemia. Nat. Genet., 41 (10), 1110-1115.

18. Shu, X.O., Long, J., \& Cai, Q. (2010). Identification of new genetic risk variants for type 2 diabetes. PLOS Genet., 6 (9), 1001127.
19. Hilal, Arikoglu, Melda, Aksoy Hepdogru, Dudu, Erkoc Kaya, Aycan, Asik, Suleyman, Hilmi Ipekci, Funda. (2014). Iscioglu IRS1 gene polymorphisms Gly972Arg and Ala513Pro are not associated with insulin resistance and type 2 diabetes risk in non-obese Turkish population. Meta Gene., 2, 579-585.

20. Besse-Patin, A., Jeromson, S., Levesque-Damphousse, P., Secco, B., Laplante, M., Estall, J.L. (2019). PGC1A regulates the IRS1: IRS2 ratio during fasting to influence hepatic metabolism downstream of insulin. Proc. Natl. Acad. Sci.,116 (10), 4285-4290.

21. Vana, DR., Adapa, D., Prasad, V., Choudhury, A. \& Ahuja, G. (2019). Diabetes mellitus types: key genetic determinants and risk assessment. Genet. Mol. Res.

22. Sliwinska, A., Kasznicki, J., \& Kosmalski, M. (2017). Tumour protein 53 is linked with type 2 diabetes mellitus. Indian J. Med. Res., 146 (2), 237-243. DOI:10.4103/ijmr.IJMR_1401_15.

23. Fiorentino, T.V., Prioletta, A., Zuo, P., \& Folli, F. (2013). Hyperglycemia-induced oxidative stress and its role in diabetes mellitus related cardiovascular diseases. Current Pharmaceutical Design,19 (32), 5695-5703.

24. Vousden, K.H., \& Prives, C. (2009). Blinded by the light: The growing complexity of p53. Cell, 137 (3), 413-431.

25. Jones, R.G., \& Thompson, C.B. (2009). Tumor suppressors and cell metabolism: a recipe for cancer growth. Genes Dev., 23 (5), 537-548.

26. Kung, C.P., \& Murphy, M.E. (2016). The role of the p53 tumor suppressor in metabolism and diabetes. $J$. Endocrinol., 231 (2), 61-75. DOI:10.1530/JOE-16-0324

27. Kathryna Fontana, Rodrigues, Nathalia Teixeira, Pietrani1, Adriana Aparecida, Bosco, Fernanda Magalhães, Freire Campos, Valéria Cristina, Sandrim, Karina Braga, Gomes (2017). IL-6, TNF- $\alpha$, and IL-10 levels/ polymorphisms and their association with type 2 diabetes mellitus and obesity in Brazilian individuals. Arch. Endocrinol. Metab., 61 (5), 438-446.

28. Boraska, V.I., Rayner, N.W., Groves, C.J., Frayling, T.M., Diakite, M., \& Rockett, K.A. (2010). Large-scale association analysis of TNF/LTA gene region polymorphisms in type 2 diabetes. BMC Med Genet., 11, 69.

29. Saxena, M., Srivastava, N., \& Banerjee, M. (2013). Association of IL-6, TNF- $\alpha$ and IL-10 gene polymorphisms with type 2 diabetes mellitus. Mol. Biol. Rep., 40 (11), 6271-6279.

30. Erdogan, M., Cetinkalp, S., Ozgen, AG., Saygili, F., Berdeli, A, Yilmaz C. Interleukin-10 (-1082G/A) gene polymorphism in patients with type 2 diabetes with and without nephropathy. Genet. Test Mol. Biomarkers, 16 (2), 91-94.

31. Zhao, Y., Li, Z., Zhang, L., Zhang, Y., Yang, Y., Tang, Y., et al. (2014). The TNF-alpha -308G/A polymorphism is associated with type 2 diabetes mellitus: an updated meta-analysis. Mol. Biol. Rep.,41 (1), 73-83.

32. Golshani, H., Haghani, K., Dousti, M., Bakhtiyaru, S. (2015). Association of TNF- $\alpha 308 \mathrm{G} /$ A polymorphism with type 2 diabetes: a case-control study in the Iranian Kurdish Ethnic Group. Osong Public Health Res. Perspect, 6 (2), 94-99.

33. Yin, Y.W., Hu, A.M., Sun, Q.Q., Zhang, B.B., Liu, H.L., Wang, Q., et al. (2012). Association between interleukin 10 gene -1082 A/G polymorphism and the risk of type 2 diabetes mellitus: a meta-analysis of 4250 subjects. Cytokine, 62 (2), 226-231. 
34. Yin, Y.W., Sun, Q.Q., Zhang, B.B., Hu, A.M., Liu, H.L., Wang, Q., et al. (2012). Association between interleukin-10 gene -592 C/A polymorphism and the risk of type 2 diabetes mellitus: a meta-analysis of 5320 subjects. Hum. Immunol., 2012, 73 (9), 960-965.

35. Prisco, A.R., Hoffmann, B.R., \& Kaczorowski, C.C. (2016), Tumor necrosis factor a regulates endothelial progenitor cell migration via CADM1 and NF-KB. Stem Cells, 34 (7), 1922-1933.

36. Vendrell, J., Fernandez-Real, J.M., \& Gutierrez, C. (2003). A polymorphism in the promoter of the tumor necrosis factor- $\alpha$ gene $(-308)$ is associated with coronary heart disease in type 2 diabetic patients, Atherosclerosis, 167 (2), 257-264.

37. Swaroop, J.J., Rajarajeswari, D., \& Naidu, J. (2012). Association of TNF- $\alpha$ with insulin resistance in type 2 diabetes mellitus. The Indian Journal of Medical Research, 135 (1), 127.

38. Geisa, Izetti Luna, Izabel, Cristina, Rodrigues da Silva, Mauro, \& Niskier Sanchez (2016). Association between -308G/A TNFA Polymorphism and Susceptibility to Type 2 Diabetes Mellitus: A Systematic Review", Journal of Diabetes Research, 6. 6. ID 6309484 Retrieved from: https://doi.org/10.1155/2016/6309484

39. Sefri, H., Benrahma, H., \& Charoute, H. (2014). TNF A -308G>A polymorphism in Moroccan patients with type 2 diabetes mellitus: a case-control study and meta-analysis. Molecular Biology Reports, 41 (9), 58055811.

40. Feng, R.N., Zhao, C., Sun, C.H., \& Li, Y. (2011). Meta-analysis of TNF $308 \mathrm{G} / \mathrm{A}$ polymorphism and type 2 diabetes mellitus. PLoS ONE, 6 (4), ID e18480.

41. Steinkasserer, A., Spurr, NK., Cox, S., Jeggo, P., \& Sim, R.B. (1992). The human IL-1 receptor antagonist gene (IL1RN) maps to chromosome 2q14-q21, in the region of the IL-1 alpha and IL-1 beta loci. Genomics, 13, 654-657.

42. Banerjee, M., Saxena, M. (2012). Interleukin-1 (IL-1) family of cytokines: role in type 2 diabetes. Clin Chim Acta., 413, 1163-1170.

43. Hülsmeyer, M., Scheufler, C., \& Dreyer, M.K. (2001). Structure of interleukin 4 mutant E9A suggests polar steering in receptor-complex formation. Acta Crystallogr. D. Biol. Crystallogr., 57, 1334-1336.

44. Dinarello CA. (1996). Biologic basis for interleukin-1 in disease. Blood, 87, 2095-2147.

45. Banerjee, M., \& Saxena, M. (2014). Genetic polymorphisms of cytokine genes in type 2 diabetes mellitus. World Journal of Diabetes, 5 (4), 493-504. DOI: 10.4239/wjd.v5.i4.493.

46. Cardellini, M., Perego, L., D'Adamo, M., Marini, M.A., Procopio, C., Hribal, M.L., Andreozzi, F., Frontoni, S., Giacomelli, M., Paganelli, M., et al. (2005). C-174G polymorphism in the promoter of the interleukin-6 gene is associated with insulin resistance. Diabetes Care, 28, 2007-2012.

47. Eskdale, J., Kube, D., Tesch, H., \& Gallagher, G. (1997). Mapping of the human IL10 gene and further characterization of the 5 ' flanking sequence. Immunogenetics, 46 (2), 120-128.

48. Chagas, B.S., Gurgel, A.P., da Cruz, H.L., Amaral, C.M., Cardoso, M.V., Silva, Neto, Jda, C., da Silva, L.A., de Albuquerque, E.M., Muniz, M.T., \& de Freitas, A.C. (2013). An interleukin-10 gene polymorphism associated with the development of cervical lesions in women infected with Human Papillomavirus and using oral contraceptives. Infect. Genet. Evol., 19, 32-37.

49. Jin, L., Sturgis, E.M., Cao, X., Song, X., Salahuddin, T., Wei, Q., \& Li, G. (2013). Interleukin-10 promoter variants predict HPV-positive tumors and survival of squamous cell carcinoma of the oropharynx. FASEB J., 27 (6), 2496-2503.

50. Scarpelli, D., Cardellini, M., Andreozzi, F., Laratta, E., Hribal, M.L., Marini, M.A., et al. (2006). Variants of the interleukin-10 promoter gene are associated with obesity and insulin resistance but not type 2 diabetes in caucasian italian subjects. Diabetes, 55 (5), 15291533.

51. Blüher, M., Fasshauer, M., Tönjes, A., Kratzsch, J., Schön, MR., \& Paschke, R. (2005). Association of interleukin-6, C-reactive protein, interleukin-10 and adiponectin plasma concentrations with measures of obesity, insulin sensitivity and glucose metabolism. Exp. Clin. Endocrinol. Diabetes, 113 (9), 534-537.

52. Al-Shukaili, A., Al-Ghafri, S., Al-Marhoobi, S., Al-Abri, S., Al-Lawati, J., \&Al-Maskari, M. (2013). Analysis of inflammatory mediators in type 2 diabetes patients. Int. J. Endocrinol., 2013, 976810.

53. Mohebbatikaljahi, H., Menevse, S., Yetkin, I., \& Demirci, H. (2009). Study of interleukin-10 promoter region polymorphisms (-1082A/G, -819T/C and -592A/C) in type 1 diabetes mellitus in Turkish population. Demirci H. J. Genet., 88 (2), 245-248.

54. Mahmoud, A.A., Sheneef, A., Sayed, A.A., Ezat,M.A.W., \& Sabet, E.A. (2016). Association of Interleukin-10 (-592A/C) gene polymorphism with its level in type 2 diabetes mellitus with and without nephropathy. J. Mol. Genet. Med., 10. 199 10.4172/1747-0862.1000199.

55. Kang, J., Liu, C.H., Lee, C.N., Li, H.Y., Yang, C.W., Huang, S.C., Lin, S.Y., \& Jou, T.S. (2019). Novel interleukin-10 gene polymorphism is linked to gestational diabetes in Taiwanese population. Front. Genet., 10, 89.

56. Edwards-Smith, C.J., Jonsson, J.R., Purdie, D.M., Bansal, A., Shorthouse, C., \& Powell, E.E. (1999). Interleukin-10 promoter polymorphism predicts initial response of chronic hepatitis $\mathrm{C}$ to interferon alfa. Hepatology, 30 (2), 526-530.

57. Helaly, M.A.H., Hatata, E.S.Z., Abu-Elmagd, M., Ibrahem, E.F., Alsaid, A., El-Aal, I.A.A., et al. (2013). Association of IL-10 and IL-6 gene polymorphisms with type 2 diabetes mellitus among Egyptian patients. Eur. J. General Med., 10 , 158-162. 10.29333/ejgm/82250.

58. Saxena, M., Srivastava, N., \& Banerjee, M. (2013). Association of IL-6, TNF- $\alpha$ and IL-10 gene polymorphisms with type 2 diabetes mellitus. Mol. Biol. Rep., 40 (11), 6271-6279.

59. Bai, H., Jing, D., Guo, A., \& Yin, S. (2014). Association between interleukin 10 gene polymorphisms and risk of type 2 diabetes mellitus in a Chinese population. J. Int. Med. Res., 42 (3),702-710.

60. Zhang, F., Yang, Y., \& Lei, H.A. (2013). Metaanalysis about the association between $-1082 \mathrm{G} / \mathrm{A}$ and $-819 \mathrm{C} / \mathrm{T}$ polymorphisms of IL-10 gene and risk of type 2 diabetes. Hum. Immunol., 74, 618-626.

61. Junhui, Chen, Yuhuan, Meng, Jinghui, Zhou, Min, Zhuo, Fei, Ling, Yu, Zhang, Hongli, Du, \& Xiaoning, Wang. (2013). Identifying candidate genes for type 2 diabetes mellitus and obesity through gene expression profiling in multiple tissues or cells. Journal of Diabetes Research, ID 970435, 9. https://doi.org/10.1155/2013/970435 
62. Locke, A.E., Kahali, B., Berndt, S.I., Justice, A.E., Pers, T.H., Day, F.R., Powell, C., Vedantam, S., Buchkovich, M.L., Yang, J., Croteau-Chonka, DC., et al. (2015). Genetic studies of body mass index yield new insights for obesity biology. Nature, 518 (7538), 197-206.

63. Shungin, D., Winkler, T.W., Croteau-Chonka, D.C., Ferreira, T., Locke, A.E., Magi, R., Strawbridge, R.J., Pers, T.H., Fischer, K., Justice, A.E., Workalemahu, T., et al. New genetic loci link adipose and insulin biology to body fat distribution. Nature, 518 (7538), 187-196.

64. Akiyama, M., Okada, Y., Kanai, M., Takahashi, A., Momozawa, Y., Ikeda, M., Iwata, N., Ikegawa, S., Hirata, M., Matsuda, K., Iwasaki, M., et al.(2017). Genomewide association study identifies 112 new loci for body mass index in the japanese population. Nat Genet., 49 (10), 1458-1467.

65. Tung, Y.C., Yeo, G.S., O'Rahilly, S., Coll, A.P. (2014). Obesity and fto: Changing focus at a complex locus. Cell Metab., 20 (5), 710-718.

66. Claussnitzer, M., Dankel, S.N., Kim, K.H., Quon, G., Meuleman, W., Haugen, C., Glunk, V., Sousa, I.S., Beaudry, J.L., Puviindran, V., Abdennur, N.A., et al. (2015). Fto obesity variant circuitry and adipocyte browning in humans. N. Engl. J. Med., 373 (10), 895-907.

67. Stratigopoulos, G., Burnett, L.C., Rausch, R., Gill, R., Penn, D.B., Skowronski, A.A., LeDuc, C.A., Lanzano, A.J., Zhang, P., Storm, D.R., Egli, D., et al. (2016). Hypomorphism of fto and rpgrip1l causes obesity in mice. J. Clin. Invest., 126 (5), 1897-1910.

68. Larder, R., Sim, M.F.M., Gulati, P., Antrobus, R., Tung, Y.C.L., Rimmington, D., Ayuso, E., Polex-Wolf, J., Lam, B.Y.H., Dias, C., Logan, D.W., et al. (2017). Obesity-associated gene tmem18 has a role in the central control of appetite and body weight regulation. Proc. Natl. Acad. Sci. U S A, 114 (35), 9421-9426.

69. Wiemerslage, L., Gohel, P.A., Maestri, G., Hilmarsson, T.G., Mickael, M., Fredriksson, R., Williams, M.J., \& Schioth, H.B. (2016). The drosophila ortholog of tmem18 regulates insulin and glucagon-like signaling. J. Endocrinol., 229 (3), 233-243.

70. Rathjen, T., Yan, X., Kononenko, N.L., Ku, M.C., Song, K., Ferrarese, L., Tarallo, V., Puchkov, D., Kochlamazashvili, G., Brachs, S., Varela, L., et al. (2017). Regulation of body weight and energy homeostasis by neuronal cell adhesion molecule 1. Nat. Neurosci. 20 (8), 1096-1103.

71. Watson, R.A., Gates, A.S., \& Wynn, E.H. (2017). Lyplal1 is dispensable for normal fat deposition in mice. Disease Models \& Mechanisms.

72. Siljee, J.E., Wang, Y., Bernard, A.A., Ersoy, B.A., Zhang, S., Marley, A., Von Zastrow, M., Reiter, JF., \& Vaisse, C.(2018). Subcellular localization of mc4r with adcy3 at neuronal primary cilia underlies a common pathway for genetic predisposition to obesity. Nat Genet.

73. Xu, H. (2013). Obesity and metabolic inflammation. Drug Discov. Today Dis. Mech., 10 (1-2), 21-25.

74. Hotamisligil, G. S. (2006). Inflammation and metabolic disorders. Nature, 444 (7121), 860-867.

75. Sun, K., Kusminski, C.M., \& Scherer, P.E. (2011). Adipose tissue remodeling and obesity. J. Clin. Invest., 121 (6), 2094-1101.

76. Cristina Oana, Margineana, Claudiu, Marginean, Mihaela, Iancuc, Valeriu, G., Moldovand, Lorena, Elena Melita, Claudia, Banescu (2019). The impact of TNFa308G >A genepolymorphism on children's overweight riskand an assessment of biochemical variables: A crosssectional single-center experience. Pediatrics and Neonatology, 60, 19-27.

77. Arner, E., Ryde'n, M., \& Arner, P.(2010). Tumor necrosis factor alpha and regulation of adipose tissue. N. Engl. J. Med., 362, 1151-1153.

78. Chang, W.T., Wang, Y.C., Chen, C.C., Zhang, S.K., Liu, C.H., Chang, F.H., et al. (2012). The-308G/A of tumor necrosis factor (TNF)-a and $825 \mathrm{C} / \mathrm{t}$ of guanidine nucleotide binding protein 3 (GNB3) are associated with the onset of acute myocardial infarction and obesity in Taiwan. Int. J. Mol. Sci., 13, 1846-1857.

79. Goodarzi, M.O., Nagpal, T., Greer, P., Cui, J., Chen, Y.I., Guo, X., et al. (2019). Consortium for the Study of Chronic Pancreatitis, Diabetes, and Pancreatic Cancer (CPDPC). Genetic risk score in diabetes associated with chronic pancreatitis versus type 2 diabetes mellitus. Clin. Transl. Gastroenterol., 10 (7), 00057.

80. Bellin, M.D., Whitcomb, D.C., \& Abberbock, J. (2017). Patient and disease characteristics associated with the presence of diabetes mellitus in adults with chronic pancreatitis in the United States. Am. J. Gastroenterol., 112, 1457-1465.

81. Gastaldelli, A., Ferrannini, E., \& Miyazaki, Y. (2004). Beta-cell dysfunction and glucose intolerance: Results from the San Antonio Metabolism (SAM) study. Diabetologia, 47, 31-39.

82. Chen, C., Cohrs, C.M., \& Stertmann, J. (2017). Human beta cell mass and function in diabetes: Recent advances in knowledge and technologies to understand disease pathogenesis. Mol. Metab., 6, 943-957.

83. Sasikala, M., Talukdar, R., \& Pavan Kumar P. (2012). Beta-cell dysfunction in chronic pancreatitis. Dig Dis Sci., 57, 1764-1772.

84. Mahajan, A., Taliun, D., \& Thurner, M. (2018). Finemapping type 2 diabetes loci to single-variant resolution using high-density imputation and islet-specific epigenome maps. Nat. Genet., 50, 1505-1513.

\section{ГЕНЕТИКА САХАРНОГО ДИАБЕТА 2 ТИПА И ЕГО СОЧЕТАНИЕ С ОЖИРЕНИЕМ И ХРОНИЧЕСКИМ ПАНКРЕАТИТОМ}

\section{Резюме}

Вступление. Гены играют важную роль в развитии сахарного диабета 2 типа (T2DM). Исследователи предложили взаимодействие между множеством генетических фракторов и фракторов окружающей 
среды, способствующих развитию заболевания. Достижения технологий генотипирования и генетической информации облегчили применение исследований ассоциаций, касающихся геномов для выявления генов восприимчивости к T2DM. В течение последнего десятилетия в рамках исследований ассоциаций генома (GWAS) с увеличением размера выборки было выявлено 144 генетических варианта в 129 локусах, ассоциированных с T2DM.

При поиске литературных источников относительно совместного генетического основания T2DM и хронического панкреатита (CP) установлено, что сочетание T2DM+CР могут обусловливать генетические варианты T2DM. Ученые обнаружили, что лица с T2DM+CP чаще страдают от избыточного веса или ожирения и имеют семейный анамнез сахарного диабета по сравнению с теми, кто страдает от CP и не имеет диабета. При T2DM+СР углубляется диссрункция бета-клеток в результате хронического воспаления и фриброза поджелудочной железы, что, вероятно, способствует гибели бета-клеток и неспособности компенсировать резистентность к инсулину, это углубляет течение диабета и панкреатита. Генетическое сопоставление T2DM+CP и T2DM по SNP, которые ассоциируются с T2DM согласно GWAS, не отражает общей роли генетики, которую можно было бы ожидать от последовательности целого генома и всестороннего анализа всех известных генетических вариантов, связанных со сложной патобиологией заболеваний поджелудочной железы и/или диабета.

Цель исследования - проанализировать современные литературные источники о генетических маркерах, которые участвуют в механизмах развития сахарного диабета 2 типа и его сочетанного течения с ожирением и хроническим панкреатитом.

Вывод. Большое количество исследований дает основания надеяться, что в будущем исследования генетики сахарного диабета при его коморбидном течении позволят разработать эффрективные профрилактические и терапевтические средства лечения, однако в настоящее время необходимо детально изучить роль полиморфизмов различных генов, особенно тех, что имеют значение в патогенезе каждого отдельного заболевания, в восприимчивости к коморбидному течению сахарного диабета 2 типа.

КЛЮЧЕВЫЕ СЛОВА: сахарный диабет 2 типа; ожирение; хронический панкреатит; коморбидность; гены.

\author{
U. P. Hevko, M. I. Marushchak
}

I. HORBACHEVSKY TERNOPIL NATIONAL MEDICAL UNIVERSITY

\title{
GENETICS OF TYPE 2 DIABETES MELLITUS AND ITS COMBINATION WITH OBESITY AND CHRONIC PANCREATITIS
}

\section{Summary}

Introduction. Genes play an important role in the development of type 2 diabetes (T2DM). Researchers have proposed interactions between many genetic and environmental factors that contribute to development of the disease.. Advances in genotyping and genetic information technology have facilitated the use of genome-related association research to identify T2DM susceptibility genes. Over the past decade, genome wide association studies (GWAS) using size selection have identified 144 genetic variants at 129 T2DM-associated loci.

When searching the literature on the common genetic background of T2DM and chronic pancreatitis (CP), it was found that the combination of T2DM + CP may be due to genetic variants of T2DM. The researchers found that people with T2DM + CP were more likely to be overweight or obese and had a family history of diabetes than those with CP who did not have diabetes. T2DM + CP exacerbates beta-cell dysfunction due to chronic inflammation and pancreatic fibrosis, which is likely to contribute to beta-cell death and the inability to compensate for insulin resistance, which exacerbates diabetes and pancreatitis. The genetic comparison of T2DM + CP and T2DM by SNPS associated with T2DM according to GWAS does not reflect the general role of genetics that could be expected from a whole genome sequence and a comprehensive analysis of all known genetic variants associated with complex pathobiology of pancreatic diseases/or diabetes.

The aim of the study - to analyze current literary sources about genetic markers that are involved in the mechanisms of type 2 diabetes mellitus and its comorbidity with obesity and chronic pancreatitis.

Conclusions. A large number of studies give reason to hope that in the future the study of the genetics of diabetes mellitus in terms of its comorbid course will develop effective prophylactic and therapeutic treatments, but now it is necessary to investigate in detail the role of polymorphisms of different genes, especially those disease, in susceptibility to comorbid type 2 diabetes.

KEY WORDS: type 2 diabetes; obesity; chronic pancreatitis; comorbidity; genes.

Отримано 04.11.20

Адреса для листування: М. І. Марущак, Тернопільський національний медичний університет імені І. Я. Горбачевського мОз України, майдан Волі, 1, Тернопіль, 46001, Україна, e-mail: marushchak@tdmu.edu.ua. 